\title{
Intrauterine exposure to copper IUDs and prenatal development in the rat
}

\author{
Susan M. Barlow, A. F. Knight and I. House* \\ Department of Pharmacology, Guy's Hospital Medical School, London SEI 9RT, and \\ *Poisons Unit, New Cross Hospital, London SE14 SER, U.K.
}

\begin{abstract}
Summary. Small coils of copper wire releasing 4-6 $\mu \mathrm{g}$ copper/coil/day were inserted between each implantation site of one uterine horn of rats on Day 9 of pregnancy. The coils remained in the uterus until Day 21 of pregnancy when the animals were killed and the uterine contents examined. There were no significant increases in the incidence of congenital malformations or growth retardation in fetuses from horns containing copper coils in comparison with fetuses from unoperated horns, sham-operated horns, or horns containing inert stainless-steel coils. Intrauterine mortality rates were significantly higher in horns containing copper coils (19-24\%) than in sham-operated or unoperated horns $(0-8 \%)$, but not significantly different from that in horns containing inert steel coils $(25 \%)$. In rats killed on Day 22 of pregnancy, after insertion of copper coils into both uterine horns on Day 9, there were significant increases in fetal brain, fetal liver, placenta and uterine copper levels in comparison with rats containing steel coils or no coils. Maternal plasma and liver copper levels were not elevated by intrauterine copper coils.
\end{abstract}

\section{Introduction}

Medicated intrauterine contraceptive devices (IUDs) containing copper are now in widespread use, yet relatively little is known about the possible effects of exposure to copper on the development of the embryo and fetus when conception occurs with the device in situ. Although implantation can occur in women in the presence of a copper IUD, copper is toxic to the blastocyst and prevents implantation in rodents and rabbits (see Oster \& Salgo, 1977). Jones, Gregson \& Elstein (1973) demonstrated inhibition of growth of human fetal cells in cultures in contact with copper IUDs, raising the question of possible teratogenicity of such devices. In the births that have been reported, when the copper IUD remained in situ for the whole or part of gestation, no increases in congenital malformations at birth were found (Tatum, Schmidt \& Jain, 1976; Guillebaud, 1976). However, the numbers involved in these series were small and examination of term infants represents only a small proportion of those conceived in the presence of a copper IUD, spontaneous abortions occurring very commonly in such cases. In a few instances when it has been possible to examine the products of conception at earlier stages of pregnancy, severe developmental arrest and intrauterine death have been noted (Gosden, Ross, McGovern \& Reid, 1979). In view of the paucity of human data, animal experiments have been undertaken to evaluate the teratogenic potential of copper IUDs.

Congenital abnormalities have been found following acute i.v. administration of copper salts to the mother during embryogenesis in the hamster (Ferm \& Hanlon, 1974) and the mouse (O'Shea \& Kaufman, 1979). However, this mode of administration may be inappropriate for the teratological evaluation of copper released from IUDs, because the embryo and fetus are chronically exposed to the copper via the uterine fluids rather than via the systemic circulation. 
An absence of malformations and no growth retardation were reported for rodent and rabbit offspring developing in a uterus containing a copper wire (Chang \& Tatum, 1973, 1975; Rasmussen \& Christensen, 1979). However, these studies utilized only a single strand of wire inserted close to the uterotubal junction, thus giving variable exposure of the embryos, depending on their location in the uterine horn relative to the copper wire. These studies may also be criticized on the grounds that the methods used for examination of the offspring for malformations were inadequate. In the study of Chang \& Tatum (1973) animals were also allowed to litter spontaneously, so abnormal offspring may have been eaten by the dam at birth before examination of the litters.

The present investigation was therefore carried out to evaluate the effects on rats of post-implantation exposure to metallic copper released from intrauterine devices, using a technique that would ensure relatively uniform, chronic exposure of all embryos and fetuses throughout the uterine horn.

\section{Materials and Methods}

\section{Animals}

Virgin female rats of the Wistar strain (purchased from Charles River, Kent, U.K.), aged about 12 weeks and weighing 200-250 g were used. For 2 weeks before mating and throughout the experiment they were kept in an isolated room under reversed lighting (07:00-19:00 h red light, 19:00-07:00 $\mathrm{h}$ white light), maintained at $21-24^{\circ} \mathrm{C}$. A pelleted diet (BP Nutrition Rat and Mouse Expanded Diet No. 3) and water were always available. The females were housed in groups of 3 and a proven male of the same strain was introduced into each cage in the morning. Males were removed and vaginal smears taken in the evening; the day of finding spermatozoa in the smear was designated Day 1 of pregnancy. The rats were weighed daily from Days 1 to 21 of pregnancy.

\section{Insertion of IUDs}

On the morning of Day 9 of pregnancy, rats were transferred from the animal room to the laboratory and assigned randomly to treatment groups. Animals receiving IUDs were anaesthetized with ether and the right or left uterine horn, selected at random, was exposed through an incision in the flank. The IUDs were made from 2 or $4 \mathrm{~cm}$ lengths of $99.9 \%$ pure copper wire, $0.1 \mathrm{~mm}$ in diameter. Both lengths of wire were coiled into spirals each approximately $2 \mathrm{~mm}$ in length and $1 \mathrm{~mm}$ in diameter. A coil was inserted between each implantation site by making a small incision on the antimesometrial side of the uterus with a size 18 intravenous cannula with cutting needle. When the incision had been made, the needle was withdrawn leaving the cannula in place. The IUD was then pushed down the cannula into the uterus and the cannula removed. In this manner, IUDs were inserted between each embryo in the uterine horn. The contralateral horn was left unoperated as a control. To control for the physical presence of devices in the uterus some animals had similar-sized coils of inert stainless-steel wire inserted into one horn leaving the contralateral horn unoperated. All copper and steel coils were weighed before insertion and their position in the uterine horn noted. To control for the stress of the operation and other possible intervening factors such as loss of uterine fluid, other animals were sham-operated-one uterine horn was exposed, incisions made between each implantation site as before, but no IUDs inserted. Animals in another group were left unoperated. After recovery from the anaesthetic all animals were returned to the animal room until killed on Day 21 of pregnancy. 
Examination of the fetuses

On Day 21 of pregnancy the rats were anaesthetized with ether and a maternal blood sample taken from the posterior vena cava for copper analysis. After cervical dislocation, the uterus was exposed and opened. In IUD-bearing animals the coils of copper or steel wire were removed, dipped in saline $(9 \mathrm{~g} \mathrm{NaCl} / \mathrm{l})$ and wiped with a tissue to remove cellular deposits, and then weighed. The number and position of live and full-term dead fetuses (no signs of maceration), late resorptions (maceration, death occurring at the fetal stage), and early resorptions (death occurring at the embryonic stage) were noted. The numbers of corpora lutea in each ovary were also noted. The fetuses were weighed individually and examined for any gross external abnormalities. Fetuses were alternately fixed in Bouin's fluid for examination of the soft tissues by the slicing technique of Wilson (1965) or in alcohol and stained with Alizarin red $\mathrm{S}$ for skeletal examination (Dawson, 1926).

\section{Maternal plasma copper estimation}

Blood samples were immediately centrifuged and the plasma stored at $4{ }^{\circ} \mathrm{C}$ until assayed by the colorimetric bathocuproin method with deproteinization (Biochemica Copper Test Combination; Boehringer Corporation Ltd, Mannheim, W. Germany), using duplicate $1 \mathrm{ml}$ aliquots from each sample.

\section{Tissue copper levels}

Each sample was wet-ashed with $1 \mathrm{ml}$ of a mixture of nitric, perchloric and sulphuric acids (20:10:1 by vol.) and dissolved in $0.5 \mathrm{ml}$ deionized water. All samples were measured by atomic absorption spectrometry (Instrumentation Laboratory, Warrington, Lancashire, U.K.) The brains were assayed by flameless atomic absorption analysis using a graphite furnace (Varian CRA 90, Walton-on-Thames, Surrey, U.K.) and the remaining tissues by flame aspiration after addition of dilute hydrochloric acid.

\section{Statistical analysis}

Differences between group means \pm s.e.m. were compared by Student's $t$ test, two-tailed. All other comparisons were examined by the Fisher exact probability test, two-tailed.

\section{Experiment 1}

\section{Results}

Animals were allocated to 3 groups representing treatment with copper IUDs (Group 1), sham-operated controls (Group 2) and untreated controls (Group 3). The IUDs were made of 2 $\mathrm{cm}$ lengths of wire. Gravimetric analysis of the copper IUDs before insertion on Day 9 and after removal on Day 21 of pregnancy showed a mean \pm s.e.m. copper loss of $48 \pm 3 \mu \mathrm{g}$, i.e. about 4 $\mu \mathrm{g} / \mathrm{coil} /$ day. Of a total of 63 coils inserted, 59 were recovered at autopsy. The majority were superficially embedded in the fibrous ring around the edge of the placentae and the remainder were free in the uterine lumen between the amniotic sacs.

Maternal plasma copper levels (mean \pm s.e.m.) on Day 21 of pregnancy were $203 \pm 5$ ( $n=$ 9), $208 \pm 12(n=10)$ and $200 \pm 5(n=10) \mu \mathrm{g} / 100 \mathrm{ml}$ in Groups 1,2 and 3 respectively. The differences between the groups are not significant.

Two rats had unilateral pregnancies, the remainder were bilateral. The only significant differences in comparisons of the 5 sub-groups of uterine horns (Table 1) were between 
Table 1. Outcome of pregnancy in rats carrying 2-cm coiled copper IUDs from Days 9 to 21 of pregnancy (Exp. 1)

\begin{tabular}{|c|c|c|c|c|c|c|c|c|}
\hline \multirow[b]{2}{*}{ Group } & \multirow{2}{*}{$\begin{array}{l}\text { No. of } \\
\text { rats }\end{array}$} & \multirow[b]{2}{*}{ Uterine horn } & \multirow{2}{*}{$\begin{array}{l}\text { No. of } \\
\text { implantation } \\
\text { sites }\end{array}$} & \multicolumn{2}{|c|}{ Fetuses } & \multicolumn{2}{|c|}{ Resorptions } & \multirow{2}{*}{$\begin{array}{l}\text { Mean } \pm \text { s.e.m. } \\
\text { fetal wt (g) }\end{array}$} \\
\hline & & & & Live & Dead & Early & Late & \\
\hline 1 (copper IUD) & 9 & $\begin{array}{l}\text { A Operated (9) } \\
\text { B Unoperated (8) }\end{array}$ & $\begin{array}{l}63 \\
42\end{array}$ & $\begin{array}{l}51 \\
39\end{array}$ & $\begin{array}{l}0 \\
0\end{array}$ & $\begin{array}{l}9 \\
2\end{array}$ & $\begin{array}{l}3 \\
1\end{array}$ & $\begin{array}{l}2.95 \pm 0.12 \\
3.02 \pm 0.10\end{array}$ \\
\hline 2 (sham-operated) & 10 & $\begin{array}{l}\text { A Operated }(10) \\
\text { B Unoperated }(9)\end{array}$ & $\begin{array}{l}57 \\
47\end{array}$ & $\begin{array}{l}55 \\
47\end{array}$ & $\begin{array}{l}0 \\
0\end{array}$ & $\begin{array}{l}1 \\
0\end{array}$ & $\begin{array}{l}1 \\
0\end{array}$ & $\begin{array}{l}2.97 \pm 0.10 \\
2.85 \pm 0.07\end{array}$ \\
\hline 3 (no operation) & 10 & Unoperated (20) & 126 & 117 & 0 & 9 & 0 & $3.12 \pm 0.05$ \\
\hline
\end{tabular}

Figures in parentheses indicate number of horns containing implantation sites.

Table 2. Results of morphological examinations of fetuses from rats in Exp. 1 carrying 2-cm coiled copper IUDs from Days 9 to 21 of pregnancy

\begin{tabular}{|c|c|c|c|c|c|}
\hline & \multicolumn{2}{|c|}{ Group 1 (copper IUD) } & \multicolumn{2}{|c|}{ Group 2 (sham-operation) } & \multirow[b]{2}{*}{$\begin{array}{c}\text { Group } 3 \\
\text { (no operation) }\end{array}$} \\
\hline & $\begin{array}{c}\text { A Operated } \\
\text { horn }\end{array}$ & $\begin{array}{l}\text { B Unoperated } \\
\text { horn }\end{array}$ & $\begin{array}{l}\text { A Operated } \\
\text { horn }\end{array}$ & $\begin{array}{l}\text { B Unoperated } \\
\text { horn }\end{array}$ & \\
\hline \multicolumn{6}{|l|}{ Gross external examination } \\
\hline Fetuses examined & 51 & 39 & 55 & 47 & 117 \\
\hline Fetuses abnormal & 2 & 0 & 0 & 0 & 0 \\
\hline \multicolumn{6}{|l|}{ Types of abnormality* } \\
\hline Omphalocoele & 1 & 0 & 0 & 0 & 0 \\
\hline Club foot & 1 & 0 & 0 & 0 & 0 \\
\hline \multicolumn{6}{|l|}{ Soft tissue examination } \\
\hline Fetuses examined & 24 & 21 & 29 & 22 & 58 \\
\hline Fetuses abnormal & 3 & 5 & 5 & 5 & 12 \\
\hline \multicolumn{6}{|l|}{ Types of abnormality* } \\
\hline Hydronephrosis & 1 & 3 & 3 & 1 & 2 \\
\hline Hydrocephaly & 0 & 1 & 2 & 0 & 1 \\
\hline Tracheobronchomegaly & 0 & 1 & 0 & 2 & 1 \\
\hline \multicolumn{6}{|l|}{ Hypertrophied tracheal/ } \\
\hline oesophageal wall & 0 & 1 & 0 & 1 & 3 \\
\hline Partly descended testis & 0 & 0 & 0 & 1 & 3 \\
\hline Haemorrhage & 2 & 0 & 1 & 0 & 2 \\
\hline \multicolumn{6}{|l|}{ Skeletal examination } \\
\hline Fetuses examined & 22 & 18 & 26 & 25 & 59 \\
\hline Fetuses anomalous & 11 & 7 & 6 & 8 & 17 \\
\hline \multicolumn{6}{|l|}{ Types of anomaly* } \\
\hline Split centra & 4 & 4 & 3 & 6 & 5 \\
\hline Kinked ribs & 6 & 3 & 3 & 4 & 12 \\
\hline Extra 14th rib(s) & 2 & 1 & 0 & 1 & 1 \\
\hline Short rib(s) & 0 & 0 & 0 & 0 & 1 \\
\hline Abnormal fusion of sternebrae & 1 & 1 & 1 & 0 & 0 \\
\hline
\end{tabular}

* Some fetuses had more than one abnormality or anomaly.

resorptions in Group $1 \mathrm{~A}$ and Group $2 \mathrm{~A}$ or $2 \mathrm{~B}(P \leqslant 0.015)$ and between Group $1 \mathrm{~A}$ and Group 3 $(P=0.03)$.

There were no significant differences between the 5 sub-groups in either the overall incidence of abnormal fetuses or in specific abnormalities and anomalies seen (Table 2).

\section{Experiment 2}

Animals in Groups 4, 5 and 6 were fitted with copper IUDs, steel IUDs or left as untreated controls, respectively. The coils were made of $4 \mathrm{~cm}$ lengths of copper or steel wire, and the mean 
\pm s.e.m. copper loss/coil was $74 \pm 4 \mu \mathrm{g}$, i.e. about $6 \mu \mathrm{g} /$ coil/day. No significant reduction in weight of the steel coils between insertion and removal was found, and microscopic examination confirmed lack of corrosion of steel coils in comparison with the copper coils which were clearly corroded.

Mean \pm s.e.m. copper levels in maternal plasma on Day 21 of pregnancy were $207 \pm 6(n=$ 13), $194 \pm 9(n=12)$ and $208 \pm 14(n=7) \mu \mathrm{g} / 100 \mathrm{ml}$ in Groups 4, 5 and 6, respectively. The differences are not significant.

Table 3. Outcome of pregnancy in rats carrying 4-cm coiled copper IUDs from Days 9 to 21 of pregnancy (Exp. 2)

\begin{tabular}{|c|c|c|c|c|c|c|c|c|}
\hline \multirow[b]{2}{*}{ Group } & \multirow{2}{*}{$\begin{array}{l}\text { No. of } \\
\text { animals }\end{array}$} & \multirow[b]{2}{*}{ Uterine horn } & \multirow{2}{*}{$\begin{array}{c}\text { No. of } \\
\text { implantation } \\
\text { sites }\end{array}$} & \multicolumn{2}{|c|}{ Fetuses } & \multicolumn{2}{|c|}{ Resorptions } & \multirow{2}{*}{$\begin{array}{l}\text { Mean } \pm \text { s.e.m } \\
\text { fetal wt (g) }\end{array}$} \\
\hline & & & & Live & Dead & Early & Late & \\
\hline 4 (copper IUD) & 13 & $\begin{array}{l}\text { A Operated (13) } \\
\text { B Unoperated (13) }\end{array}$ & $\begin{array}{l}75 \\
95\end{array}$ & $\begin{array}{l}57 \\
91\end{array}$ & $\begin{array}{l}0 \\
0\end{array}$ & $\begin{array}{r}16 \\
4\end{array}$ & $\begin{array}{l}2 \\
0\end{array}$ & $\begin{array}{l}2.96 \pm 0.08 \\
3.04 \pm 0.07\end{array}$ \\
\hline 5 (steel IUD) & 14 & $\begin{array}{l}\text { A Operated (14) } \\
\text { B Unoperated (13) }\end{array}$ & $\begin{array}{r}98 \\
110\end{array}$ & $\begin{array}{r}75 \\
108\end{array}$ & $\begin{array}{l}0 \\
0\end{array}$ & $\begin{array}{r}13 \\
2\end{array}$ & $\begin{array}{r}10 \\
0\end{array}$ & $\begin{array}{l}2.83 \pm 0.08 \\
2.86 \pm 0.07\end{array}$ \\
\hline 6 (no operation) & 7 & Unoperated (14) & 102 & 102 & 0 & 0 & 0 & $2.79 \pm 0.11$ \\
\hline
\end{tabular}

Figures in parentheses indicate number of horns containing implantation sites.

Table 4. Results of morphological examinations of fetuses from rats carrying 4-cm coiled copper IUDs from Days 9 to 21 of pregnancy (Exp. 2)

\begin{tabular}{|c|c|c|c|c|c|}
\hline & \multicolumn{2}{|c|}{ Group 4 (copper IUD) } & \multicolumn{2}{|c|}{ Group 5 (steel IUD) } & \multirow[b]{2}{*}{$\begin{array}{c}\text { Group } 6 \\
\text { (no operation) }\end{array}$} \\
\hline & $\begin{array}{c}\text { A Operated } \\
\text { horn }\end{array}$ & $\begin{array}{l}\text { B Unoperated } \\
\text { horn }\end{array}$ & $\begin{array}{c}\text { A Operated } \\
\text { horn }\end{array}$ & $\begin{array}{l}\text { B Unoperated } \\
\text { horn }\end{array}$ & \\
\hline \multicolumn{6}{|l|}{ Gross external examination } \\
\hline Fetuses examined & 57 & 91 & 75 & 108 & 102 \\
\hline Fetuses abnormal & 0 & 2 & 0 & 0 & 2 \\
\hline \multicolumn{6}{|l|}{ Types of abnormality* } \\
\hline Omphalocoele & 0 & 0 & 0 & 0 & 2 \\
\hline Club foot & 0 & 1 & 0 & 0 & 0 \\
\hline Spina bifida & 0 & 1 & 0 & 0 & 0 \\
\hline \multicolumn{6}{|l|}{ Soft tissue examination } \\
\hline Fetuses examined & 30 & 44 & 37 & 54 & 51 \\
\hline Fetuses abnormal & 10 & 7 & 6 & 9 & 7 \\
\hline \multicolumn{6}{|l|}{ Types of abnormality* } \\
\hline Hydronephrosis & 1 & 2 & 2 & 4 & 2 \\
\hline Tracheobronchomegaly & 5 & 0 & 2 & 0 & 2 \\
\hline Large unfolded oesophagus & 3 & 2 & 1 & 1 & 2 \\
\hline Diaphragmatic hernia & 1 & $\mathbf{0}$ & 0 & 0 & 1 \\
\hline Partly descended testis & 0 & $\mathbf{0}$ & 1 & 1 & 0 \\
\hline Haemorrhage & 0 & 3 & 1 & 3 & 1 \\
\hline \multicolumn{6}{|l|}{ Skeletal examination } \\
\hline Fetuses examined & 27 & 47 & 38 & 54 & 51 \\
\hline Fetuses anomalous & 7 & 13 & 11 & 7 & 10 \\
\hline \multicolumn{6}{|l|}{ Types of anomaly* } \\
\hline Split centra & 0 & 3 & 2 & 2 & 3 \\
\hline Kinked ribs & 4 & 5 & 9 & 4 & 9 \\
\hline Extra 14th rib(s) & 3 & 5 & 0 & 0 & 0 \\
\hline Short rib(s) & 0 & 1 & 2 & 1 & 1 \\
\hline Fused ribs & 1 & 0 & 0 & 0 & 0 \\
\hline
\end{tabular}

* Some fetuses had more than one abnormality or anomaly. 
The outcome of the pregnancies is shown in Table 3. There was a significant increase in the incidence of resorptions in Groups $4 \mathrm{~A}$ and $5 \mathrm{~A}$ in comparison with Groups $4 \mathrm{~B}$ and $5 \mathrm{~B}(P<$ 0.005 ). There was no significant difference between Groups $4 \mathrm{~A}$ and $5 \mathrm{~A}$.

There were no significant differences in the overall incidence of abnormalities (Table 4). The only significant difference in the incidence of specific soft tissue abnormalities was an excess of tracheobronchomegaly in Group 4A compared with Group 4B $(P<0.02)$. However, the difference between Group 4A and Group 6 was not significant. The only significant difference in the incidence of skeletal anomalies was a slight excess of extra 14th rib in fetuses from Group 4B in comparison with Group $6(P<0.05)$.

\section{Experiment 3}

To ascertain whether copper released from the IUDs penetrated into the fetuses, pregnant rats were treated as follows. On Day 9 of pregnancy, copper IUDs were inserted as described previously between each embryo in both uterine horns of 2 rats (Group 7). In another 2 rats, steel IUDs were similarly inserted in both horns (Group 8). One rat was left as an unoperated control. The females were killed on Day 22 of pregnancy, and samples of maternal liver and uterus, all fetal brains, fetal livers and placentae were removed for copper analysis. Fetal brain, fetal liver and placental copper levels were significantly elevated in Group 7 in comparison with tissues from animals in Group 8 or the unoperated control (Table 5). In Group 7 variance between fetuses in tissue copper levels was low, suggesting relatively uniform exposure of the embryos and fetuses. Maternal liver levels of copper were not elevated in Group 7 (5.0 and 6.8 $\mu \mathrm{g} / \mathrm{g})$ compared with Group $8(4.9$ and $5.2 \mu \mathrm{g} / \mathrm{g})$ or the unoperated control $(4.5 \mu \mathrm{g} / \mathrm{g})$. Uterine copper levels were considerably elevated in Group $7(33 \cdot 1$ and $21.3 \mu \mathrm{g} / \mathrm{g})$ compared with values in Group $8(2.0$ and $2.1 \mu \mathrm{g} / \mathrm{g})$ and the control animal $(1.8 \mu \mathrm{g} / \mathrm{g})$.

Table 5. Mean \pm s.e.m. (range in parentheses) tissue copper levels $(\mu \mathrm{g} / \mathrm{g}$ ) after insertion of copper IUDs from Days 9 to 22 of pregnancy (Exp. 3)

\begin{tabular}{|c|c|c|c|c|}
\hline Group & $\begin{array}{c}\text { No. of } \\
\text { samples }\end{array}$ & Fetal brain & Fetal liver & Placenta \\
\hline 7 (copper IUD) & 14 & $2 \cdot 0 \pm 0 \cdot 2 \ddagger(1 \cdot 3-3 \cdot 9)$ & $26.8 \pm 1.5^{*}(19.4-39 \cdot 1)$ & $5.8 \pm 0.8^{*}(3 \cdot 1-14 \cdot 0)$ \\
\hline 8 (steel IUD) & 22 & $1.3 \pm 0.1 \quad(0.9-2 \cdot 3)$ & $12.9 \pm 0.3 \quad(10.4-15.7)$ & $2 \cdot 4 \pm 0 \cdot 1 \quad(1 \cdot 8-3 \cdot 3)$ \\
\hline 9 (control) & 12 & $1 \cdot 3 \pm 0.1 \quad(0.9-2 \cdot 1)$ & $9 \cdot 2 \pm 0 \cdot 3 \quad(8 \cdot 0-10 \cdot 6)$ & $2.6 \pm 0.1 \quad(2 \cdot 1-3.0)$ \\
\hline
\end{tabular}

* $P<0.001$ compared with steel IUD or control groups.

$\dagger P<0.001$ compared with steel IUD group and $<0.05$ compared with controls.

\section{Discussion}

The present study demonstrates that it is possible to achieve relatively uniform exposure of embryos and fetuses to copper by inserting small coils of wire between each implantation site, and that the majority of offspring survive this procedure. The coils remain in the uterus throughout pregnancy and do not puncture the amniotic sacs. We therefore suggest that this technique is more appropriate for teratological evaluation of medicated IUDs in animals than the single strands of wire used previously.

Comprehensive examination of the offspring for structural abnormalities confirmed that copper had no significant teratogenic or growth-retarding effect in the rat. The incidence of major malformations was low in all groups and the minor disturbances that were seen in all groups are known to be common spontaneous malformations in the strain of rat used (Perraud, 1976). The neural tube and cardiac defects observed by Ferm \& Hanlon (1974) in the hamster and O'Shea \& Kaufman (1979) in the mouse, following i.v. injection of copper salts at particular 
stages of embryogenesis may be due to the mode of administration which gives transient but very high copper levels in the maternal blood. Although copper ions released from intrauterine wire are absorbed systemically in the rat (Okerere, Sternlieb, Morell \& Scheinberg, 1972), the present study shows that they are insufficient to elevate maternal plasma copper levels, a finding also shown for women with copper IUDs (Hagenfeldt, 1972; Moo-Young, Tatum, Wan \& Lane, 1975; Daunter \& Elstein, 1976; Kupfersztain, Menache, Rubinstein \& Halbrecht, 1976; Anteby, Ben Bassat, Yarkoni, Aboulafia \& Sadovsky, 1978). Copper levels in the rat maternal liver were not elevated, but the copper released from the IUDs did penetrate the fetus, as has also been shown in the rabbit (Moo-Young \& Tatum, 1974). Fetal brain copper levels were increased by $65 \%$ and fetal liver levels by more than $100 \%$ in copper-exposed offspring compared with those from mothers with steel IUDs or no IUDs. Tissue copper levels in unexposed offspring were similar to those reported for untreated rats (Terao \& Owen, 1977).

The lack of teratogenicity of copper released from IUDs in comparison with systemically administered copper cannot therefore be attributed to lack of exposure of the conceptuses. Moreover, in the present study the embryos were exposed to copper throughout organogenesis. The IUDs were inserted on the morning of Day 9 of pregnancy, which corresponds to the primitive-streak stage marking the onset of organogenesis, and is well before the time of neural tube closure on Days 10-11 (Edwards, 1968; Shephard, 1973). However, the present experiments do not exclude the possibility that copper-induced alterations of uterine or embryonic biochemistry, which may not be fully expressed for several hours, might be teratogenic.

The question of whether intrauterine exposure to copper causes embryonic or fetal death remains unclear. In the present experiments, intrauterine mortality rates of 19 and $24 \%$ in copper IUD horns were significantly higher than in sham-operated $(4 \%)$ or untreated controls $(0$ and $8 \%$ ), but were no higher than in horns carrying inert steel IUDs (25\%). Most of the deaths occurred before Day 12 of pregnancy. These results suggest that the deaths were probably due to trauma from the insertion and the physical presence of devices in the uterus, rather than to any specific effect of copper. However, when rats were allowed to litter, mean litter size at birth was significantly reduced in animals bearing copper IUDs in both horns to $8.3 \pm 0.4$ young (mean \pm s.e.m.) compared with $10.0 \pm 0.6$ young in those bearing steel IUDs or $13.6 \pm 0.6$ young in untreated controls (unpublished results). A significant reduction in litter size at birth was reported after insertion of copper wire on Day 6 of pregnancy in the rat (Chang \& Tatum, 1973) and there was an increasingly lethal effect of copper wire in comparison with platinum wire on the offspring as pregnancy progressed (Chang \& Tatum, 1975). However, Rasmussen \& Christensen (1979) found no increase in offspring mortality in mice with intrauterine copper wire killed just before term.

The question of the relative exposures of human and rat conceptuses developing in the presence of a copper IUD must be considered. Gosden et al. (1979) have measured copper levels in 3 human fetuses at 10,13 and 17 weeks developing with a copper IUD in the uterus; brain, kidney and liver levels were not elevated in comparison with those in a single unexposed fetus of 15 weeks gestation. However, Alderman (1976) has reported a 2-fold elevation in serum copper and a 4-fold elevation in ceruloplasmin levels in cord blood from a neonate that had been exposed to a copper IUD throughout gestation and died shortly after delivery. Only crude estimates of relative exposure rates may be made, since the human data are so scanty and the relative distribution of copper between uterine tissue, amniotic fluid, placenta and fetus is not known. In women, the average amount of copper released from a copper-7 device is around 70 $\mu \mathrm{g} /$ day (Zipper, Segura, Medel \& Torres, 1972). This is distributed between the uterus and its contents, weighing around $40 \mathrm{~g}$ at the beginning of pregnancy and $5700 \mathrm{~g}$ at term. This can be compared with 25-40 $\mu \mathrm{g}$ copper/day released from the IUDs in a single uterine horn of rats weighing $0.5 \mathrm{~g}$ at the start of pregnancy and around $40 \mathrm{~g}$ at term. It therefore seems likely that the exposure of the rat conceptuses to copper was much greater than that in women. 
We thank the Ford Foundation, New York, for financial support; and the Orthodontics Department, Guy's Hospital, for help in making the steel IUDs.

\section{References}

Alderman, B. (1976) Cord blood copper concentrations in the presence of a copper releasing intrauterine contraceptive device. Proc. R. Soc. Med. 69, 823825.

Anteby, S.O., Ben Bassat, H.A., Yarkoni, S., Aboulafia, Y. \& Sadovsky, E. (1978) The effect of intrauterine devices containing zinc and copper on their levels in serum. Fert. Steril. 29, 30-34.

Chang, C.C. \& Tatum, H.J. (1973) Absence of teratogenicity of intrauterine copper wire in rats, hamsters and rabbits. Contraception 7, 413-434.

Chang, C.C. \& Tatum, H.J. (1975) Effect of intrauterine copper wire on resorption of fetuses in rats. Contraception 11, 79-84.

Daunter, B. \& Elstein, M. (1976) Serum levels of copper caeruloplasmin and caeruloplasmin oxidase activity in women using copper-containing intrauterine devices and in women taking combined oral contraceptives. J. Obstet. Gynaec. Br. Commonw. 80, 644-647.

Dawson, A.B. (1926) A note on the staining of the skeleton of cleared specimens with alizarin red S. Stain Technol. 1, 123-124.

Edwards, J.A. (1968) The external development of the rabbit and rat embryo. Adv. Teratol. 3, 239-263.

Ferm, V.H. \& Hanlon, D.P. (1974) Toxicity of copper salts in hamster embryonic development. Biol. Reprod. 11, 97-101.

Gosden, C., Ross, A., McGovern, A. \& Reid, W. (1979) The state of the device and copper levels in the products of conception in women becoming pregnant with a copper-bearing IUD in situ. J. Reprod. Fert. $55,437-446$.

Guillebaud, J. (1976) IUD and congenital malformation. Br. med.J. i, 1016.

Hagenfeldt, K. (1972) Intrauterine contraception with the copper-T device. Contraception 6, 37-54.

Jones, R.W., Gregson, N.M. \& Elstein, M. (1973) Effect of copper-containing intrauterine contraceptive devices on human cells in culture. Br. med. $J$. ii, 520-522.

Kupfersztain, C.C., Menache, R., Rubinstein, J. \& Halbrecht, I. (1976) Copper concentration in women's endometrium and peripheral blood after prolonged use of intrauterine devices. Reproducion 3, 27-32.
Moo-Young, A.J. \& Tatum, H.J. (1974) Copper levels in maternal and fetal tissues of rabbits bearing intrauterine copper wires. Contraception 9, 487-496.

Moo-Young, A.J., Tatum, H.J., Wan, L.S. \& Lane, M.E. (1975) Copper levels in certain tissues of rhesus monkeys and women bearing copper IUDs. In Analysis of Intrauterine Contraception, pp. 439-457. Eds F. Hefnawi \& S. J. Segal. North-Holland, Amsterdam.

Okerere, T., Sternlieb, 1., Morell, A.G. \& Scheinberg, 1.H. (1972) Systemic absorption of intrauterine copper. Science, N.Y. 177, 358-360.

O'Shea, K.S. \& Kaufman, M.H. (1979) Influence of copper on the early post-implantation mouse embryo: an in vivo and in vitro study. Wilhelm Roux Arch. Dev. Biol. 186, 297-308.

Oster, G. \& Salgo, M.P. (1977) Copper in mammalian reproduction. Adv. Pharmac. Chemother. 14, 327409.

Perraud, J. (1976) Levels of spontaneous malformations in the CD rat and CD-1 mouse. Lab. Anim. Sci. 26, 293-300.

Rasmussen, B.B. \& Christensen, N. (1979) Teratogenicity of intrauterine copper wire in mice. Acta path. microbiol. scand. Sect. A 87, 261-264.

Shephard, T.H. (1973) Catalog of Teratogenic Agents. Johns Hopkins University Press, Baltimore.

Tatum, H.J., Schmidt, F.H. \& Jain, A.K. (1976) Management and outcome of pregnancies associated with the copper $\mathrm{T}$ intrauterine contraceptive device. Am. J. Obstet. Gynec. 126, 869-878.

Terao, T. \& Owen, C.A. (1977) Copper metabolism in pregnant and postpartum rat and pups. Am. J. Physiol. 232, E172-E179.

Wilson, J.G. (1965) Methods for administering agents and detecting malformations in experimental animals. In Teratology: Principles and Techniques, pp. 262277. Eds J. G. Wilson \& J Warkany. University of Chicago Press.

Zipper, J., Segura, R., Medel, M. \& Torres, L. (1972) Development of a new type of contraceptive. In New Concepts in Contraception, pp. 201-212. Eds M. Potts \& C. Wood. MTP, Lancaster.

Received 15 July 1980 